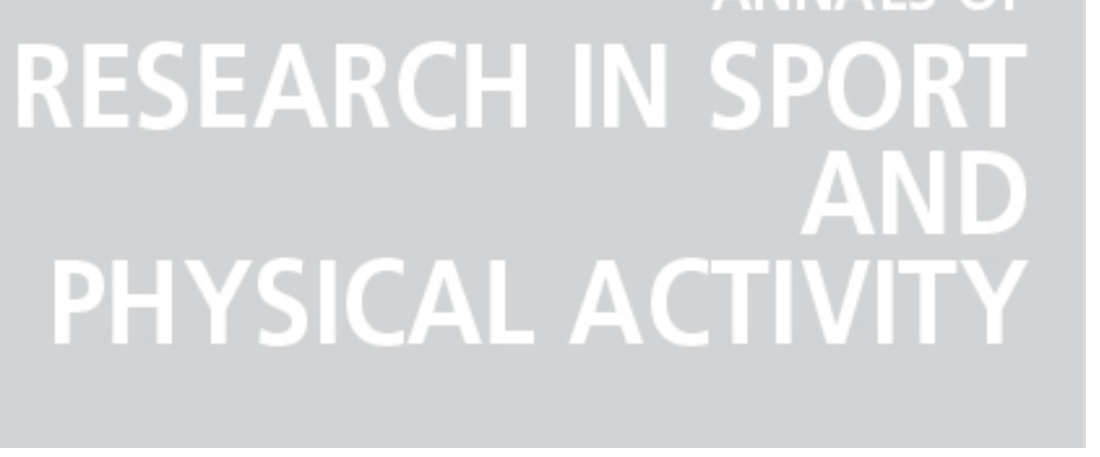

\title{
Potential of tear fluid antimicrobial proteins to evaluate risk of upper respiratory
} illness

Autor(es): $\quad$ Hanstock, Helen G.; Edwards, Jason P.; Walsh, Neil P.

Publicado por: Imprensa da Universidade de Coimbra

URL persistente:

URl:http://hdl.handle.net/10316.2/44113

DOI:

DOI:https://doi.org/10.14195/2182-7087_ex2018_50

Accessed : $\quad$ 26-Apr-2023 10:19:07

A navegação consulta e descarregamento dos títulos inseridos nas Bibliotecas Digitais UC Digitalis, UC Pombalina e UC Impactum, pressupõem a aceitação plena e sem reservas dos Termos e Condições de Uso destas Bibliotecas Digitais, disponíveis em https://digitalis.uc.pt/pt-pt/termos.

Conforme exposto nos referidos Termos e Condições de Uso, o descarregamento de títulos de acesso restrito requer uma licença válida de autorização devendo o utilizador aceder ao(s) documento(s) a partir de um endereço de IP da instituição detentora da supramencionada licença.

Ao utilizador é apenas permitido o descarregamento para uso pessoal, pelo que o emprego do(s) título(s) descarregado(s) para outro fim, designadamente comercial, carece de autorização do respetivo autor ou editor da obra.

Na medida em que todas as obras da UC Digitalis se encontram protegidas pelo Código do Direito de Autor e Direitos Conexos e demais legislação aplicável, toda a cópia, parcial ou total, deste documento, nos casos em que é legalmente admitida, deverá conter ou fazer-se acompanhar por este aviso. 


\section{ANNALS OF RESEARCH IN SPORT AND PHYSICAL ACTIVITY}




\section{POTENTIAL OF TEAR FLUID ANTIMICROBIAL PROTEINS TO EVALUATE RISK OF UPPER RESPIRATORY ILLNESS}

Helen G. Hanstock'; Jason P. Edwards²; Neil P. Walsh

KEYWORDS: Tear biomarkers, Infection, Immune, Non-invasive, Monitoring

Transmission of upper respiratory tract infections (URTI) has been demonstrated at the ocular surface ${ }^{(1)}$. Thus, the immunological profile of the tear fluid likely plays an important role in host defence against URTI, and moreover provides a non-invasive medium for assessment of immune status. We recently demonstrated that tear secretory $\lg \mathrm{A}(\mathrm{S} \lg \mathrm{A})$ has potential as a biomarker of URTI risk ${ }^{(2)}$. It is likely that several other antimicrobial proteins abundant in tears such as lactoferrin (Lf) and lysozyme (Lys) contribute to host defence at the ocular surface ${ }^{(3)}$.

\section{PURPOSE}

To explore the potential of tear Lf and Lys to evaluate risk of subsequent URTI independently and in combination with tear SIgA data from the same subjects presented in Hanstock et al. ${ }^{(2)}$.

\section{METHODS}

Forty healthy, physically active subjects were recruited during the common-cold season. Subjects reported upper respiratory symptoms (URS) daily and provided weekly tear sam-

\footnotetext{
1 Mid Sweden University.

2 Bangor University

Email: helen.hanstock@miun.se
} 
ples for 4 weeks. If URS were reported for $\geq 48 \mathrm{~h}$, subjects provided a nasopharyngeal swab for identification of common-cold pathogens using RT-PCR and a tear sample. Following an episode of URS, subjects reported daily URS until they had been symptom-free for 4 weeks at which time a 'Recovery' tear sample was collected. Tear Lf and Lys concentration was determined using ELISA.

\section{RESULTS}

Eleven subjects reported episodes of URS; nine of whom returned positive virology tests for human rhinovirus (URTI). Twenty-two subjects remained symptom-free during the monitoring period (Healthy) and seven were excluded due to non-compliance. Tear Lys concentration (Lys-C) and secretion rate (Lys-SR) were lower in URTI vs. Healthy ( $p<0.01$ and $p<0.05$ ) but there was no difference in Lf-C and Lf-SR. The potential of Lf and Lys to assess URS risk was determined by comparing Lf and Lys the week before URS with Recovery samples. Tear Lf-C, Lf-SR and Lys-C were not altered before URS, whereas Lys-SR tended to be reduced in the week before URS $(p<0.1)$. A binary logistic regression incorporating tear flow rate, Lys-C, Lf-C and SlgA-C as predictors was able to correctly identify subjects at risk of URS in the next week with $70 \%$ accuracy (95\% Cl: $54-85 \%$ ) but only $27 \%$ sensitivity. Conclusion: Although tear Lys was decreased during URTI, the new model including tear Lys and Lf was not able to improve upon the utility of tear SIgA alone to assess URS risk in this small cohort. Larger datasets will be required to evaluate and optimise model performance for models based on tear SIgA, possibly in combination with other biomarkers, to predict URTI.

\section{REFERENCES}

1. Bischoff WE, Reid T, Russell GB, Peters TR. Transocular Entry of Seasonal Influenza-Attenuated Virus Aerosols and the Efficacy of N95 Respirators, Surgical Masks, and Eye Protection in Humans. Journal of Infectious Diseases. 2011 Jul 15;204(2):193-9.

2.Hanstock, H.G., Walsh, N.P., Edwards, J.P., Fortes, M.B., Cosby, S.L., Nugent, A., Curran, T., Coyle, P.V., Ward, M.D. and Yong, X.H.A., 2016. Tear fluid SIgA as a noninvasive biomarker of mucosal immunity and common cold risk. Med Sci Sports Exerc, 48, pp.569-77.

3. McDermott AM. Antimicrobial compounds in tears. Experimental eye research. 2013 Dec 31;117:53-61. 